\title{
Leopard and spotted hyena densities in the Lake Mburo National Park, southwestern Uganda
}

\author{
Aleksander Braczkowski ${ }^{\text {Corresp., } 1,2}$, Ralph Schenk ${ }^{3}$, Dinal Samarasinghe ${ }^{4}$, Duan Biggs ${ }^{1}$, Allie Richardson ${ }^{5}$, Nicholas \\ Swanson $^{3}$, Merlin Swanson ${ }^{3}$, Arjun Dheer ${ }^{6}$, Julien Fattebert ${ }^{7,8}$ \\ 1 Resilient Conservation Group, Centre for Planetary Health and Food Security, Griffith University, Nathan, Queensland, Australia \\ 2 School of Natural Resource Management, Nelson Mandela University, George Campus, George, Western Cape, South Africa \\ 3 Mihingo Lodge, Kampala, Uganda \\ 4 Wildlife Research and Nature Conservation Foundation (WRNCF), Colombo, Sri Lanka \\ 5 School of Biological Science, The University of Queensland, Brisbane, Queensland \\ 6 Department of Evolutionary Ecology, Leibniz Institute for Zoo and Wildlife Research, Berlin, Germany \\ 7 Wyoming Cooperative Fish and Wildlife Research Unit, Department of Zoology and Physiology, University of Wyoming, Laramie, Wyoming, United States \\ 8 Centre for Functional Biodiversity, School of Life Sciences, University of KwaZulu-Natal, Durban, KwaZulu-Natal, South Africa
}

Corresponding Author: Aleksander Braczkowski

Email address: a.braczkowski@griffith.edu.au

Robust measures of animal densities are necessary for effective wildlife management. Leopards (Panthera pardus)and spotted hyenas (Crocuta Crocuta) are higher order predators that are data deficient across much of their East African range and in Uganda, excepting for one peer-reviewed study on hyenas, there are presently no credible population estimates for these species. A lack of information on the population status and even baseline densities of these species has ramifications as leopards are drawcards for the photo-tourism industry, and along with hyenas are often responsible for livestock depredations from pastoralist communities. Leopards are also sometimes hunted for sport. Establishing baseline density estimates for these species is urgently needed not only for population monitoring purposes, but in the design of sustainable management offtakes, and in assessing certain conservation interventions like financial compensation for livestock depredation. Accordingly, we ran a single-season survey of these carnivores in the Lake Mburo National Park of south-western Uganda using 60 remote camera traps distributed in a paired format at 30 locations. We analysed hyena and leopard detections under a Bayesian spatially explicit capture-recapture (SECR) modelling framework to estimate their densities. This small national park $\left(370 \mathrm{~km}^{2}\right)$ is surrounded by Bahima pastoralist communities with high densities of cattle on the park edge (with regular park incursions). Leopard densities were estimated at 6.31 individuals $/ 100 \mathrm{~km}^{2}$ (posterior SD = $1.47,95 \% \mathrm{Cl}=3.75-9.20)$, and spotted hyena densities were 10.99 individuals $/ 100 \mathrm{~km}^{2}$, 
but with wide confidence intervals (posterior $\mathrm{SD}=0.33,95 \% \mathrm{Cl}=5.63-17.37$ ). Leopard and spotted hyena abundance within the boundaries of the national park were 24.87 (posterior SD 7.78) and 39.07 individuals (posterior = SD 13.51) respectively. Leopard densities were on the middle end of SECR studies published in the peer-reviewed literature over the last five years while spotted hyena densities were some of the first reported in the literature using SECR, and similar to a study in Botswana which reported 11.80 spotted hyenas $/ 100 \mathrm{~km}^{2}$. Densities were not noticeably lower at the park edge, and in the southwest of our study site, despite repeated cattle incursions into these areas. We postulate that the relatively high densities of both species in the region could be owed to impala Aepyceros melampus densities ranging from 16.6 - $25.6 \mathrm{impala} / \mathrm{km}^{2}$. Another, potential explanatory variable (albeit a speculative one) is the absence of interspecific competition from African lions (Panthera leo), which became functionally extinct (there is only one male lion present) in the park nearly two decades ago. This study provides the first robust population estimate of these species anywhere in Uganda and suggests leopards and spotted hyenas continue to persist in the highly modified landscape of Lake Mburo National Park. 
1 Leopard and spotted hyena densities in the Lake Mburo National Park, southwestern Uganda 2

3 Alexander Braczkowski ${ }^{1,2}, *$, Ralph Schenk ${ }^{3}$, Dinal Samarasinghe ${ }^{4}$, Duan Biggs ${ }^{1}$, Allie Richardson ${ }^{5}$, Nicholas

4 Swanson $^{3}$, Merlin Swanson ${ }^{3}$, Arjun Dheer ${ }^{6}$, Julien Fattebert ${ }^{7,8}$

5

$6{ }^{1}$ Resilient Conservation Group, Environmental Futures Research Institute, Griffith University, 170 Kessels

7 Road, Nathan, Queensland 4111, Australia

8 2School of Natural Resource Management, Nelson Mandela University, George Campus, George 6530,

9 South Africa

$10{ }^{3}$ Mihingo Lodge, P.O. Box 28142, Kampala, Uganda

$11{ }^{4}$ Wildlife Research and Nature Conservation Foundation (WRNCF), 487/4 old road Kottawa, Pannipitiya, 1210230 Sri Lanka

$13{ }^{5}$ School of Biological Sciences, The University of Queensland, St. Lucia, Queensland 4067, Australia

14 6Department of Evolutionary Ecology, Leibniz Institute for Zoo and Wildlife Research, Berlin 10315, 15 Germany

$16{ }^{7}$ Wyoming Cooperative Fish and Wildlife Research Unit, Department of Zoology and Physiology, University 17 of Wyoming, Laramie, WY 82071, USA

$18{ }^{8}$ Centre for Functional Biodiversity, School of Life Sciences, University of KwaZulu-Natal, Durban 4000, 19 South Africa

*Corresponding Author: alexander.braczkowski@gmail.com

Short Title: Leopard and spotted hyena densities in Lake Mburo

Words in Abstract: 409

Word count: 4922 excluding references

Number of figures: 3

Number of tables: 5

\section{KEYWORDS}

Panthera pardus, Crocuta crocuta, spatially explicit capture-recapture, population size, East Africa, human-carnivore conflict 


\section{ABSTRACT}

34 Robust measures of animal densities are necessary for effective wildlife management. Leopards (Panthera pardus) and spotted hyenas (Crocuta crocuta) are higher order predators that are data deficient across much of their East African range and in Uganda, excepting for one peer-reviewed study on hyenas, there are presently no credible population estimates for these species. A lack of information on the population status and even baseline densities of these species have ramifications as leopards are drawcards for the photo-tourism industry, and along with hyenas are often responsible for livestock depredations from pastoralist communities. Leopards are also sometimes hunted for sport. Establishing baseline density estimates for these species is urgently needed not only for population monitoring purposes, but in the design of sustainable management offtakes, and in assessing certain conservation interventions like financial compensation for livestock depredation. Accordingly, we ran a single-season survey of these carnivores in the Lake Mburo National Park of south-western Uganda using 60 remote camera traps distributed in a paired format at 30 locations. We analysed hyena and leopard detections under a Bayesian spatially explicit capture-recapture (SECR) modelling framework to estimate their densities. This small national park $\left(370 \mathrm{~km}^{2}\right)$ is surrounded by Bahima pastoralist communities with high densities of cattle on the park edge (with regular park incursions). Leopard densities were estimated at 6.31 individuals/100 $\mathrm{km}^{2}$ (posterior $\mathrm{SD}=1.47,95 \% \mathrm{Cl}=3.75-9.20$ ), and spotted hyena densities were 10.99 individuals/100 $\mathrm{km}^{2}$, but with wide confidence intervals (posterior $\mathrm{SD}=0.33,95 \% \mathrm{Cl}=5.63-17.37$ ). Leopard densities were on the middle end of SECR studies published in the peer-reviewed literature over the last five years while spotted hyena densities were some of the first reported in the literature using SECR ( $n=5$ studies since 2011), and similar to a study in Botswana which reported 11.80 spotted hyenas $/ 100 \mathrm{~km}^{2}$. Densities were not noticeably lower at the park edge, and in the southwest of our study site, despite repeated cattle incursions into these areas. We postulate that the relatively high densities of both species in the region could be owed to impala Aepyceros melampus densities ranging from $16.6-25.6 \mathrm{impala} / \mathrm{km}^{2}$. Another, potential explanatory variable (albeit a speculative one) is the absence of interspecific competition from African lions (Panthera leo), which became functionally extinct (there was only one male lion present) in the park nearly two decades ago. This study provides the first robust population estimate of these species anywhere in Uganda and suggests leopards and spotted hyenas continue to persist in the highly modified landscape of Lake Mburo National Park.

62 


\section{INTRODUCTION}

66 Precise measures of animal densities represent one of the most fundamental precursors for effective wildlife management (Karanth 1995, White and Burnham 1999, Duangchantrasiri et al. 2015, Rayan and Linkie 2015). Density estimates assist inter alia with species assessments (Jacobson et al. 2016), the setting of harvest quotas (Balme et al. 2009b), and in gauging the viability of individual populations (Sollmann et al. 2011). Measures of animal abundance and density are becoming increasingly critical for species that are exposed to significant anthropogenic pressures, are constrained to small habitat patches, and are important to the economies of developing nations (O'Bryan et al. 2018).

Large carnivores naturally occur at relatively low densities and have large space requirements (Balme et al. 2009b, Gopalaswamy et al. 2012b). Anthropogenic sources of mortality at the edges of small reserves can therefore depress carnivore densities, even within protected areas because animals move beyond their boundaries and are killed (e.g. Balme et al. 2009b, Woodroffe and Ginsberg 1998). In Uganda, most protected areas are relatively small, isolated and have high human pressures at their edges (Venter et al. 2016). Additionally, most Ugandan national parks and wildlife reserves are bordered by livestock rearing communities, and large carnivores regularly kill livestock in these areas (Ochieng et al. 2015). Consequently, large carnivores are often killed in retaliation for livestock killing, and damage through poisoning, trapping or shooting (Tweheyo et al. 2012).

Leopard (Panthera pardus) and spotted hyena (Crocuta crocuta) are examples of species which have impacts on the livelihoods of local communities in Uganda (Ochieng et al. 2015). Both species were responsible for 1,102 attacks on cattle, sheep and goats on the edge of Lake Mburo National Park (hereafter LMNP) (spotted hyenas $n=762$ or $69 \%$, leopards $n=340$ or $31 \%$ between January 2009December 2018, Braczkowski et al. 2020c). Consequently, at least 19 leopards were killed on the boundary of LMNP in a 4-year period from 2003-2006 (CITES CoP 14 Proposal 3), and two hyena clans (each >14 individuals in size) that were regularly viewed by tourists were poisoned in 2007 (Ralph Schenk pers.comm). However, both species are also important for the wildlife-viewing tourism (Van der Meer et al. 2016) and in Uganda in 2018 alone, 1585 people purchased a night game drive permit for leopard viewing in LMNP, equating to US\$47550 in revenue for the Ugandan Wildlife Authority (A. Kule pers. comm.). This often leads to contradictory management goals, where one entity seeks higher densities to maximize tourism revenue, and the other seeks lower densities due to livelihood loss from conflict. 
97 the design of sustainable management offtakes and also in assessing the impact of conservation 98 interventions on carnivores and communities (e.g. Financial compensation, the erection of livestock 99 protection bomas etc.).

100

101 To address these concerns, we sought to estimate the population abundance and densities of leopards

102 and spotted hyenas in the LMNP, south-western Uganda. LMNP is a small, protected area that lacks much

103 of the charismatic megafauna found elsewhere in the country e.g. mountain gorillas (Gorilla beringei 104 beringei), chimpanzees (Pan troglodytes), African elephants (Loxodonta africana) and lions (Panthera leo).

105 Consequently, leopards and spotted hyenas are important tourism draws for the region. This is even more

106 important as African lions became functionally extinct in LMNP in the early 2000's (Uganda Wildlife

107 Authority 2010). There is also legal trophy hunting of leopards on LMNP's edge and high rates of human-

108 leopard conflict on its boundary (Braczkowski et al. 2020c). This study represents the first assessment of

109 leopards undertaken in a protected area system in Uganda and provides one of the first spatially explicit

110 estimates of spotted hyena densities in the literature. This study produces a baseline single season

111 snapshot into the population densities for both species to inform conservation management in the region

112 and to better track the impacts of conservation interventions.

113

\section{STUDY AREA}

115 We studied leopards and spotted hyenas in the LMNP $\left(370 \mathrm{~km}^{2}\right)$, Kiruhura district, Western Uganda $\left(30^{\circ}\right.$

$11647^{\prime}-31^{\circ} 04^{\prime} \mathrm{E}, 00^{\circ} 30^{\prime}-0^{\circ} 30^{\prime} \mathrm{S}$, Figure 1). The LMNP forms part of the Akagera savanna ecosystem which 117 extends from Rwanda and north-western Tanzania down into south-western Uganda (Menaut 1983, Van

118 de Weghe 1990). LMNP experiences a bimodal annual rainfall pattern (October - December and February

119 - June) and annual rainfall and temperatures average $800 \mathrm{~mm}$ and $28^{\circ} \mathrm{C}$, respectively (Moe et al. 2016).

120 The woody vegetation in the park is characterized by dry Acacia savanna dominated by Acacia hockii, 121 woodlands, thickets and swamps which occur on the edges of Lake Kachera and Mburo (Rannestad et al. 122 2006). The most common grasses include (Loudetia kagerensis), (Chloris gayana), and (Sporobolus 123 pyramidalis). LMNP supports one of two remaining population of impala (Aepyceros melampus) in 124 Uganda, the most common and preferred prey of the African leopard (Hayward et al. 2006). The park also 125 harbours Plains zebra (Equus quagga), Cape buffalo (Syncerus caffer), Defassa waterbuck (Kobus 126 ellipsiprymnus defassa), bushbuck (Tragelaphus scriptus) and warthog (Phacochoerus africanus, 127 Rannestad et al. 2006). There is only one male lion ( $\geq 10$ years old) in LMNP (a vagrant thought to have 128 come from Akagera National Park, in neighbouring Rwanda). LMNP is bordered by a matrix of small human 
129 settlements, small-scale subsistence crops, dairy ranches and communal grazing lands (Ochieng et al. 130 2015).

131

132 Park history, introduction of trophy hunting and human-carnivore conflict

133 Although the national park itself is small, much of the former park area - which is now mainly used as

134 cattle rangeland - still has considerable woodlands, thickets and natural vegetation and Rannestad et al.

135 (2006) noted higher densities of bushbuck, impala, reedbuck (Redunca redunca), waterbuck and zebra 136 outside of the national park's borders during the wet season. The region surrounding LMNP has a trophy

137 hunting scheme which was initiated due to increasing complaints by communities, stating that the 138 increasing wildlife was a nuisance (Ochieng et al. 2015). The leopard is only allowed to be hunted when a 139 problem animal tag is made available by Ugandan Wildlife Authority (hereafter UWA) attributed to 140 repeated stock killing and damage. Although harvests of leopards since 2007 have been low in Uganda 141 (17 skins, skulls and trophies exported from 2009-2017), attempts were made to have the species 142 downgraded from CITES Appendix 1 to Appendix 2 and proposed a quota of 50 leopards annually (despite 143 the lack of even a single abundance estimate anywhere in the country, CITES CoP 14 Proposal 3). Currently, 14428 leopards are available annually on quota country-wide. Contrastingly, in Africa, hyenas are often taken 145 opportunistically by trophy hunters rather than as prized trophy animals and we could not find any 146 evidence that they are an actively hunted species in Uganda (see for example: http://www.uganda147 wildlife-safaris.com).

149 METHODS

\section{Camera trapping}

151 This research was granted approval by the Uganda Wildlife Authority under permit number: 152 UWA/COD/96/05 as approved by the Executive Director Mr Stephen Masaba. We implemented one single 153 season camera-trap survey for 53 days in the LMNP from 26 July 2018 - 16 September 2018 using 154 Cuddeback ${ }^{\mathrm{TM}}$ 20-megapixel Long Range IR camera traps (powered by 8 AA batteries each) set in a paired 155 format. The survey encompassed 30 camera trap sites distributed across the national park (Figure 1), but 156 we omitted camera traps in the far western sector of the park due to a lack of road access. Each camera 157 trap site consisted of two camera traps, each mounted to a $1 \mathrm{~m}$ steel pole $40 \mathrm{~cm}$ from the ground. We 158 positioned each camera perpendicular to a vehicle track or game trail at a $60-75^{\circ}$-angle to facilitate early 159 detection of leopards and spotted hyenas. We set our camera traps on roads, vehicle tracks, trails and 160 drainage lines, as these are regularly used by leopards and spotted hyenas as travel and hunting routes 
161 (Balme et al. 2009a, Balme et al. 2009b, Henschel et al. 2014). We checked traps every 4-7 days to correct

162 for animal damage, replace memory cards and to assess battery functionality (Braczkowski et al. 2016).

163 Camera traps were set to burst mode and took five images every time the infrared sensor was triggered.

164 We set camera traps in a way as to ensure that at least one camera-trap site was present in an area 165 corresponding to the smallest female leopard home-range recorded in the literature $\left(30 \mathrm{~km}^{2}\right.$; Bailey 1993 , 166 and $23 \mathrm{~km}^{2}$ in Fattebert et al. 2016), as these are smaller than male leopards and spotted hyenas. Our 167 camera spacing was $2.1 \mathrm{~km}$ (5-7 camera stations per female home range). We did choose this camera 168 spacing in order to ensure that no animal had a zero probability of capture (Karanth and Nichols 1998).

169 The identity of individual leopards and spotted hyenas was determined by their unique rosette and spot 170 patterns (Miththapala et al. 1989, O’Brien and Kinnaird 2011). For leopards, we were able to classify the 171 sex of individuals by using distinctive morphological cues such as the presence of testes and the enlarged 172 dewlap and sagittal crest in males (Balme et al. 2012, Braczkowski et al. 2015a).

173

174 The first and eighth author assigned individual identity to temporally unique photographs and only 175 included into the final density estimation process individuals for which there was consensus (Bahaa-el-din 176 et al. 2016). We excluded images that were blurred, were too far away from the camera trap and those 177 where observers could not agree on identity. For the purpose of building capture histories with known 178 unique individual identities, we used both flanks of leopards in our analysis (Figure 2). Spotted hyenas, 179 however, often walked around cameras and did not present a clear flank on both sides of a single animal, 180 and several individuals moved around a single camera at the same time. To avoid mismatching flanks and 181 mistakenly double-count individuals, we chose the flank of hyenas with the highest number of 182 photographs recorded during our survey (Henschel et al. 2014).

\section{SECR modelling}

185 We estimated leopard and spotted hyena densities and abundance in LMNP using Bayesian spatially 186 explicit capture re-capture modelling. By incorporating spatial information into the detection process, the 187 method does not suffer from the "edge effects" common to non-spatial estimators (Gopalaswamy et al. 188 2012a). The modelling approach uses a state (leopard and spotted hyena population size and locations in 189 the landscape) and observation process (Royle et al 2009, Gopalaswamy et al 2012b). To accurately 190 estimate the densities and home-range centres of both species we generated potential activity centres 191 across our study area $\left(370 \mathrm{~km}^{2}\right)$ in the form of $0.336 \mathrm{~km}^{2}$ (i.e. $580 \mathrm{~m} \times 580 \mathrm{~m}$, Gopalaswamy et al. 2012a) 192 equally spaced pixels. This state-space assumes the number of leopards and spotted hyenas found in these 
193 pixels are defined by a binomial process, but because spotted hyenas are often found in groups, the state

194 process allows for $\geq 2$ spotted hyenas to have an activity centre in the same pixel (Gopalaswamy et al.

195 2012a). The state space encompassed the LMNP, and a buffer of $25 \mathrm{~km}$ around it (including the eastern

196 rangelands bordering the park, Kanyaryeru and the southern farmlands). We masked out all human

197 settlements and water bodies inside and surrounding the national park, as leopards and spotted hyenas

198 are unlikely to have their home-range centres directly in such unsuitable habitats (Royle et al. 2009,

199 Gopalaswamy et al. 2012a, Braczkowski et al. 2016). We used a classical capture re-capture sampling

200 design and created a standard capture re-capture matrix (trap locations, individual leopards or hyenas

201 and sampling occasions, e.g., du Preez et al. 2014, Braczkowski et al. 2016, Williams et al. 2017). Large

202 terrestrial carnivores regularly feature differences at the sex-level in their home-range sizes and capture

203 probability (Gopalaswamy et al. 2012b, Braczkowski et al. 2016). Differences in movements of animals

204 based upon sex can affect the observation process in spatial capture-recapture (Sollmann et al. 2011). To

205 factor this into our models, we included a sex-specific covariate in the observation process and accounted

206 for different capture probability for leopards. We did not do this for hyenas as the female spotted hyenas

207 feature a pseudo-scrotum which makes sexing difficult, and the visibility of males' testes was often

208 obscured by their large tail (Hamilton et al. 1986).

209

210 In SECR modelling, $\sigma$ is the scale parameter, and represents the rate of decline in the detection rate as the

211 location of the animal's activity centre moves away from a camera trap station. $\lambda 0$ is the basal encounter

212 rate and can be defined as the encounter rate of an animal whose activity centre lies exactly at a camera

213 trap station. The detection rates of an individual animal decline with increasing distance between its

214 activity centre and camera trap location (Borchers and Efford 2008, Royle et al., 2009) and the parameter

$215 \theta$ defines the shape of the detection function. If this parameter is estimated from the given data, the

216 shape of the detection function could define how an animal utilizes space or resources in its environment

217 (Elliot and Gopalaswamy 2017). In practice, since encounter rates are so small, they are approximately

218 equal to detection probabilities (Efford 2019). We either used a fixed $\theta$ at 0.75 (Elliot and Gopalaswamy

219 2017) and 1 (Gaussian form, Royle et al., 2009) or estimated a continuous $\theta$ parameter from the data. The

220 complementary log-log link was used to convert encounter rates to Bernoulli detections, therefore, in our

221 models, the probability of detecting a leopard or hyena $\mathrm{i}$ in pixel $\mathrm{j}$ is defined by a complementary log-log

222 function of covariates.

Peer] reviewing PDF | (2021:03:58862:2:0:CHECK 13 Sep 2021) 
223 We assessed six a priori models for leopards, and two for spotted hyenas (parameter definitions are

224 presented in Table 1). Model 1 estimated the detection function (this is defined by $\theta$ ) and assumed that 225 detection probability is sex specific:

226

227

$$
\operatorname{clog} \log (\pi i j)=\log \left(\lambda_{0}\right)+\beta_{\text {sex }}-f\left[\operatorname{dist}\left(i, j \mid \vartheta, \sigma_{\text {sex }}\right)\right]
$$

228

229

where, $\pi_{\mathrm{ij}}$ describes the detection probability on a given sampling occasion, which is a function of the basal encounter rate $\lambda_{0}$ and distance between the activity center of individual $i$ and pixel $j, \theta$ and sex-specific $\sigma_{\text {sex }}$. The specific form of this detection function is:

232

$$
f[\operatorname{dist}(i, j) \mid \vartheta, \sigma \operatorname{sex}]=\exp \left\lceil\frac{-\operatorname{dist}(i, j)^{2 \theta}}{2 \sigma_{\text {sex }}^{2}}\right\rceil
$$

234

Model 2 was based on the assumption that detection probability is not dependent on sex, (i.e., $\beta$ sex was fixed at 0 ). The rate of decline in detection probability $(\sigma)$ however, remained sex specific because this parameter is also linked to the movement of animals.

238

Model 3 as with model 2, had $\beta$ sex set at 0 while the detection function was set at $\theta=0.75$

Model 4 was based on the assumption that basal encounter rate is dependent on sex, thus, $\beta$ sex was fixed parameter $\theta$ was fixed at 0.75 .

Model 5 assumed basal encounter rate is dependent on sex but rate of decline in detection probability was independent of sex. The detection function parameter was fixed at $\theta=0.75$.

Model 6 was the same as model 1 but the detection function parameter $(\theta)$ was fixed at 1 . covariate. 
253 We used Bayesian Markov Chain Monte Carlo (MCMC) simulation and the Metropolis-Hastings algorithm

254 (Tierney 1994) to run our models in the package SCRbayes (https://github.com/jaroyle/SCRbayes) in the 255 programming environment R Version 3.6.1 (R Development Core Team 2019). We set each model to run

256 8862-Table_5_REVISED.docx for 20,000 iterations including a burn-in of 5,000 iterations but we adjusted

257 this further if we did not arrive at a standing distribution, (refining burn-in period and initial iterations

258 further). Each model was set to run for 4 chains (Elliot and Gopalaswamy 2017). Model adequacy was

259 determined by examining the Bayesian $p$-value on individual encounters (Royle et al. 2009). MCMC 260 convergence was assessed using the Gelman-Rubin diagnostic (Gelman \& Rubin 1992). The five input files

261 necessary to run these analyses and accompanying $R$ scripts are provided in the supporting information

262 section of this manuscript (Supporting information 3). Although we were principally interested in

263 estimating density, we also computed posterior mean abundance across the study area of the greater

264 LMNP system.

265

266

\section{RESULTS}

267 We recorded a total of 1,444 trap nights during the 53-day survey period. Cameras were not functional

268

269

270

271

272

273

274

275

276

277

278

279

280

281

282

283 due to animal interference and battery failures for 146 trap nights, and these were not included in the SECR analysis. We recorded a total of 61 temporally independent (ie. animals counted only once in a 24hour period) detections of leopards during our camera trap survey, and 51 spotted hyena detections (Table 2). From these we recorded 112 and 42 useable flanks for leopards and hyenas respectively (51 right hyena flanks vs 32 left flanks; 9 excluded due to not identifiable or juvenile hyena). We identified 20 unique leopards (six adult males and 14 adult females), and 27 (no sex noted) spotted hyenas. This equates to a detection rate of 1.38 leopards and 1.87 spotted hyenas per 100 trap-nights.

\section{Density estimates and Model diagnostics}

Bayesian p-values for all our leopard density models ranged from 0.61- 0.76 (Supporting Information 1), indicating an adequate model fit (extremities $0.15-0.85$ ). Convergence of models was indicated by a mean potential shrink reduction factor of $<1.2$ for each parameter for each model (Gelman and Rubin 1992, Supporting Information 1). The same assessment of model adequacy was recorded for a model where sigma was estimated without a sex effect for the estimates of spotted hyena density (Bayesian $p=$ 0.61 and shrink reduction factor for all parameters $<1.2$, Supporting Information 2). Model selection using marginal likelihood from Dey et al. (2018) indicated that model 5, which considered basal encounter rate 
284 to be dependent on sex but detection probability independent of sex had the highest log likelihood score 285 (log likelihood $=-55,615.56$, Table 3).

\section{Leopard density estimates}

287 Using model 5, leopard density for LMNP was estimated at 6.31 individuals $/ 100 \mathrm{~km}^{2}$ (posterior SD 1.47, $28895 \% \mathrm{Cl}$ range $=3.75-9.20$ ). The posterior mean abundance for the Lake Mburo National Park was 24.87 289 (posterior SD 7.78) using this model. The leopard movement parameter or sigma $\sigma$ for males and females 290 from this model was $1.33 \mathrm{~km}$ (this movement parameter is a measurement of how far animals travel in 291 the landscape and is related to home range size; Braczkowski et al. 2020b). The next best-ranked 292 candidate model (model number 4) which considered sex as a factor affecting detection probability 293 estimated a movement parameter of $1.60 \mathrm{~km}$ for males and $0.59 \mathrm{~km}$ for females.

\section{Hyena density estimates}

296 For spotted hyenas, right flanks were recorded with the highest frequency (Table 2).

297 Spotted hyena density for LMNP was estimated at 11.00 individuals $/ 100 \mathrm{~km}^{2}$ (posterior SD $=0.32,95 \% \mathrm{Cl}$ 298 range $=5.57-17.09)$ using model 1 . The spotted hyena movement parameter $\sigma$ for both sexes combined was $3.15 \mathrm{~km}$. The posterior mean abundance for the entire state space buffer was 39.07 spotted hyenas (posterior $=$ SD 13.51, Table 3).

301

302

\section{DISCUSSION}

We provide a robust estimate of leopard densities and abundance in the LMNP ecosystem, southwestern Uganda, and also the first SECR assessment for spotted hyenas in Uganda as a whole (however these had wider confidence intervals when compared to leopards). These estimates are important baselines for the future monitoring of leopard and spotted hyena populations in the LMNP, one which experiences both significant levels of human-carnivore conflict and trophy hunting (Braczkowski et al. 2020c). Robust estimates of population abundance and densities are a critical cornerstone for tracking changes and trends in carnivore populations over time (e.g. Balme et al. 2009b, Williams et al. 2017). In this humancarnivore conflict-prone area, it is unknown whether retaliatory killings following depredation on livestock are sustainable in the long term, especially as the LMNP is small and isolated from other larger protected areas. Previous research has shown that carnivore populations in small, isolated national parks cannot

313 withstand the edge effects from human-carnivore conflict (e.g. from cattle farming) and trophy hunting 314 (Woodroffe and Ginsberg 1998, Balme et al. 2009b). 


\section{Possible explanations for observed leopard and hyena densities}

319 Leopard densities in LMNP were on the mid-tier of estimates recorded in the recent literature using SECR

320 studies ( $n=15$ studies from 2013 - 2018, Table 4). The leopard densities we observed at 6.31 321 individuals $/ 100 \mathrm{~km}^{2}$ are somewhat surprising given a) the small size of LMNP, and b) the high levels of

322 conflict between these two carnivores and the livestock rearing communities on the park edge

323 (Braczkowski et al. 2020c). Contrastingly, the hyena densities were similar to a SECR study in uMkhuze

324 Game Reserve, northern Kwa-Zulu Natal, South Africa (a savanna system) which estimated a density of 32510.59 individuals $/ 100 \mathrm{~km}^{2}$ (posterior SD = 2.10, De Blocq 2014), and a study in Botswana's Moremi 326 estimated 11.80 (posterior SD $=2.60$, Rich et al. 2019). We postulate that three factors may be 327 contributing to these densities, namely 1) the availability of preferred prey, 2) the existence of a 328 compensation scheme that reimburses ranchers after depredation events on the LMNP edge (Braczkowski 329 et al. 2020c), and 3) the functional extinction of lions in the region dating back to over a decade ago (at 330 the time of publication there was only one male lion ( $\geq 10$ years old) in this ecosystem, a vagrant thought 331 to have come from Akagera National Park, in neighbouring Rwanda). LMNP is one of only two protected 332 areas in Uganda with a population of impala, the most preferred prey of leopards (Hayward et al. 2006).

333 The most recent studies implemented using distance sampling by Rannestad et al. (2006) and Kisame et

334 al. (2018) found significant populations of impala within LMNP and on the adjacent cattle farmlands at $33525.6 \pm 4.8$ individuals $/ \mathrm{km}^{2}$ in the 2003 study of Rannestad et al. (2006), and 15.3 and 16.6 individuals $/ \mathrm{km}^{2}$ 336 in the 2014 and 2016 sampling periods of Kisame et al. (2018). Importantly Rannestad et al. (2006) also 337 found a higher number of impala groups ( 80 vs 58 ) and total individuals (348 vs 255) in the community 338 lands adjoining the park than within the national park in the wet season of 2003. Similarly, Kisame et al. 339 (2018) estimated that nearly half of the impala population in the LMNP and surrounding ranches was 340 found on non-protected land. Other densities of key leopard prey species estimated in this study included $3413.8 \pm 0.8$ individuals $/ \mathrm{km}^{2}$ for bushbuck (higher densities outside) and warthogs (12.3 \pm 2.9 individuals $/ \mathrm{km}^{2}$, 342 densities lower outside national park, Rannestad et al. 2006). The availability of these species at relatively 343 high densities both inside and beyond the edge of LMNP could be one reason for the densities of leopards 344 and hyenas we observed in our study. It also remains unclear whether the functional extinction of lions in 345 the LMNP has contributed to some level of release of leopards and spotted hyenas. For example, from 346 their study of leopard densities in three Kwazulu-Natal Parks, South Africa, Ramesh et al. (2016) found 347 that where lion distribution overlapped spatially with leopards, densities of leopards decreased 
348

349

350

351

352

353

354

355

356

357

358

359

360

361

362

363

364

365

366

367

368

369

370

371

372

373

374

375

376

377

378

379

drastically. However this pattern of leopard suppression by lions was not observed in the Sabi Sand Game Reserve, a protected area system adjacent to the Kruger National Park where leopard-lion observations have been recorded since the 1970's (Balme et al. 2017b).

Spotted hyenas and lions have an intricate relationship of facilitation and competition (Périquet et al. 2015). Unlike leopards, spotted hyenas do not show a negative correlation with lion presence in Africa (Périquet et al. 2015) despite intraguild predation and the negative impact that lions can have on hyena reproduction (Watts and Holekamp 2008). Spotted hyenas may benefit from the presence of lions - and vice versa - due to the high dietary overlap between the species leading to scavenging and kleptoparasitic opportunities (Hayward 2006, Davidson et al. 2019). Observed positive correlations in lion and spotted hyena density in many parts of Africa may also be a result of their similar preferred prey base. In Zambia, M'soka et al. (2016) found a high density of spotted hyenas in a lion-depleted ecosystem, though it was suggested that the observed density was driven by the availability of wildebeest, as in Höner et al. (2005). The spotted hyena densities we observed in our study were similar to an unpublished SECR study from uMkhuze Game Reserve, KwaZulu-Natal, South Africa (De Blocq 2014), and a study from Botswana's Moremi (Rich et al. 2019). Estimates of spotted hyena densities using non-SECR methods, from African savanna sites range widely from $2-20$ individuals $/ 100 \mathrm{~km}^{2}$ in the Kruger National Park, South Africa (Mills et al. 2001) to over 100 individuals/100 km² in the Ngorongoro Crater, Tanzania (Kruuk, 1972; Höner et al. 2005). The spotted hyena density from this study is similar those from protected areas in southern Africa but lower than those in other East African savannas (Holekamp and Dloniak 2010). It is important to note that the majority of previous estimates have been produced using non-spatial methods (e.g. callups and mark-resight), and to our knowledge our study is one of the first to use a SECR approach for spotted hyena density estimation (Table 5). SECR densities are typically lower for large carnivores due to other methods making more generalized extrapolations over a given unit area (Noss et al. 2012) which may explain the difference between our results and those from other savanna systems in East Africa where non-spatial methods were used.

It is noteworthy that areas of high density between the species do not appear to overlap (Figure 3). Previous studies have suggested that spotted hyenas can be significant kleptoparasites of leopard kills, forcing them to cache or avoid areas with high hyena density (Balme et al. 2017a; Davis et al., 2021). Similarly, another study detected low temporal overlap between leopards and spotted hyenas in Tanzania, which was postulated to be due to the avoidance of kleptoparasitism (Havmøller et al. 2020). 
380 Therefore, the avoidance of kleptoparastism may drive the differences in space use between the species

381 we detected in LMNP but would require further investigation.

382

383 Limitations and future monitoring of large carnivores in LMNP

384 Our study is limited by a lack of temporal replication. This is important as we could not generate critical

385 population parameters such as emigration, immigration, birth and death (e.g. Karanth et al. 2006). These

386 parameters are indicators of population trend and are ultimately required to ascertain the true trajectory

387 of a given population. It should also be remembered that spotted hyenas live in fission-fusion clans and

388 may move together in groups or singularly. It remains to be seen if this clan-living structure may cause

389 biases in estimates of density and other parameters in our sampling situation. For example, López-Bao

390 (2018) show that wolf densities are not significantly affected by group living. Similarly, Bischof et al.,

391 (2020) suggest that if there are low to moderate levels of gregariousness observed in group living

392 individuals, there is little overdispersion that occurs in the estimation of the detection function and scale

393 parameter. However, if gregariousness is high, overdispersion may be observed in confidence intervals

394 around parameter estimates, affecting the veracity of estimates. Although our study represents the first

395 snapshot of this leopard and spotted hyena population, it is important as a baseline estimate from which

396 future estimates can be made against (eg. Balme et al. 2009b). Our study also failed to quantify any

397 relationships between hyenas and leopards, which in some sites have been shown to positively influence

398 one another's occupancy in a landscape (Comley et al. 2020).

399

400 There is a growing conflict between large carnivores and humans in the greater LMNP ecosystem

401 (Braczkowski et al. 2020c). The impacts of spotted hyenas and leopards on cattle, sheep and goats in the

402 Bahima pastoral lands adjacent to LMNP are significant, and leopards and spotted hyenas were the source

403 of $98 \%(n=1102)$ of depredation events recorded between January 2009 - December 2018 in the region

404 (Braczkowski et al. 2020c). Other studies have highlighted spotted hyenas as a primary source of livestock

405 loss, which combined with their negative public image, makes them vulnerable to retaliatory killing (Kissui

406 2008; Holmern et al.2007). While spotted hyenas are behaviourally flexible, populations are slow to

407 recover following even moderate reduction (Benhaiem et al. 2018). This pattern has also been observed

408 for African leopards (e.g. Balme et al. 2009b). For this reason, the continued monitoring of the LMNP

409 spotted hyena and leopard population is crucial from a human-carnivore conflict perspective. Continued

410 population monitoring of leopards is also critical in the context of trophy-hunting of leopard and leopard

411 prey, which is allowed on properties adjoining the LMNP. Even though legal harvests of leopards in Uganda

Peer] reviewing PDF | (2021:03:58862:2:0:CHECK 13 Sep 2021) 
412 since 2007 have been low (17 skins, skulls and trophies exported from 2009 - 2017), and 28 leopards are

413 available on quota country-wide annually (Braczkowski et al. 2015b), it is critical to monitor these 414 populations annually or biannually as they can rapidly decline under even modest harvest pressures 415 (Balme et al. 2010). The way in which quotas have been set in Uganda for leopards was also done using a 416 non-robust method which related rainfall to leopard densities (CITES CoP 14 Proposal 3).

417

\section{CONCLUSION}

419 We aimed at providing the first leopard and spotted hyena population density estimates for the Lake Mburo ecosystem in Uganda, a small but regionally important national park with significant cattle farming on its edge. We found that leopard occur at a relatively high density of 6.3 individuals $/ 100 \mathrm{~km}^{2}$, probably due to a combination of factors such a high local prey density and an absence of lions. Spotted hyena densities of were also relatively high, with several factors putatively at play, including abundance of prey including livestock, the absence of lions, and the general tolerance of hyenas for human disturbance. Our estimates form a robust baseline for future population monitoring to inform both the design of sustainable management offtakes, and conservation interventions for the two species in the region.

427

\section{ACKNOWLEDGEMENTS}

We are grateful to the Ugandan Wildlife Authority for their support in the implementation of this study, particularly Aggrey Rwetsiba and Kule Asa Musinguzi. The Scientific Exploration Society, Rufford Foundation, Mihingo Lodge, and the Siemiatkowski Foundation are thanked for their help with funding and supporting Alex Braczkowski while he was in the field.

\section{REFERENCES}

435 Bailey, T.N. (1993). The African leopard. Columbia University Press, New York.

Bahaa-el-din, L., Sollmann, R., Hunter, L. T., Slotow, R., Macdonald, D. W., \& Henschel, P. (2016). Effects Biological Conservation, 199, 1-9.

Balme, G.A., Hunter, L.T.B. \& Slotow, R. (2009a). Evaluating methods for counting cryptic carnivores. J. Wildl. Mgmt. 73, 433-441.

Balme, G.A., Slotow, R. \& Hunter, L.T.B. (2009b). Impact of conservation interventions on the dynamics and persistence of a persecuted leopard population. Biol. Conserv. 142, 2681-2690. 
443

444

445

446

447

448

449

450

451

452

453

454

455

456

457

458

459

460

461

462

463

464

465

466

Balme, G.A., Slotow, R.O.B. and Hunter, L.T. (2010). Edge effects and the impact of non-protected areas in carnivore conservation: leopards in the Phinda-Mkhuze Complex, South Africa. Animal conservation, 13(3), pp.315-323.

Balme, G.A., Hunter, L. and Braczkowski, A.R. (2012). Applicability of age-based hunting regulations for African leopards. PloS one, 7(4).

Balme, G. A., Miller, J. R., Pitman, R. T., \& Hunter, L. T. (2017a). Caching reduces kleptoparasitism in a solitary, large felid. Journal of Animal Ecology, 86(3), 634-644.

Balme, G. A., Pitman, R. T., Robinson, H. S., Miller, J. R., Funston, P. J., \& Hunter, L. T. (2017b). Leopard distribution and abundance is unaffected by interference competition with lions. Behavioral Ecology, 28(5), 1348-1358.

Benhaiem, S., Marescot, L., East, M. L., Kramer-Schadt, S., Gimenez, O., Lebreton, J. D., \& Hofer, H. (2018). Slow recovery from a disease epidemic in the spotted hyena, a keystone social carnivore. Communications biology, 1(1), 1-12.

Bischof, R., Dupont, P., Milleret, C., Chipperfield, J., \& Royle, J. A. (2020). Consequences of ignoring group association in spatial capture-recapture analysis. Wildlife Biology, 2020(1).

Borchers, D. L., \& Efford, M. G. (2008). Spatially explicit maximum likelihood methods for capturerecapture studies. Biometrics, 64(2), 377-385.

Braczkowski, A.R., Balme, G.A., Dickman, A., Macdonald, D.W., Fattebert, J., Dickerson, T., Johnson, P. and Hunter, L. (2015a). Who bites the bullet first? The susceptibility of leopards Panthera pardus to trophy hunting. PloS one, 10(4).

Braczkowski, A. R., Dickman, A., Macdonald, D. W., Johnson, P. J., Balme, G. A., Lindsey, P. A., \& Hunter, L. T. (2015b). Rosettes, Remingtons and Reputation: Establishing potential determinants of leopard (Panthera pardus) trophy prices across Africa. African Journal of Wildlife Research, 45(2), 158-168.

Braczkowski AR, Balme GA, Dickman A, Fattebert J, Johnson P, Dickerson T, Macdonald DW, Hunter L. (2016). Scent Lure Effect on Camera-Trap Based Leopard Density Estimates. PLoS One: e0151033.

Braczkowski, A., Gopalaswamy, A. M., Nsubuga, M., Allan, J., Biggs, D., \& Maron, M. (2020b). Detecting early warnings of pressure on an African lion (Panthera leo) population in the Queen Elizabeth Conservation Area, Uganda. Ecological Solutions and Evidence, 1(1), e12015.

Braczkowski, A., Fattebert, J., Schenk, R., O'Bryan, C., Biggs, D., \& Maron, M. (2020c). Evidence for increasing human-wildlife conflict despite a financial compensation scheme on the edge of a Ugandan National Park. Conservation Science and Practice, 2(12), e309.

Peer] reviewing PDF | (2021:03:58862:2:0:CHECK 13 Sep 2021) 
474 Comley, J., Joubert, C. J., Mgqatsa, N., \& Parker, D. M. (2020). Lions do not change rivers: complex

475 African savannas preclude top-down forcing by large carnivores. Journal for Nature Conservation, 476125844.

477 Davidson, Z., Dupuis-Desormeaux, M., Dheer, A., Pratt, L., Preston, E., Gilicho, S., Mwololo, M., Chege, 478 G., MacDonald, S., Doncaster, C. P. (2019). Borrowing from Peter to pay Paul: managing threatened 479 predators of endangered and declining prey species. PeerJ, 7, e7916.

480 Davis, R. S., Yarnell, R. W., Gentle, L. K., Uzal, A., Mgoola, W. O., \& Stone, E. L. (2021). Prey availability 481 and intraguild competition regulate the spatiotemporal dynamics of a modified large carnivore 482 guild. Ecology and Evolution.

483 De Blocq, A.D. (2014). Estimating spotted hyaena (Crocuta crocuta) population density using camera trap 484 data in a spatially explicit capture-recapture framework (Doctoral dissertation, University of Cape 485 Town).

486 Dey, S., Delampady, M., \& Gopalaswamy, A. M. (2019). Bayesian model selection for spatial capture487 recapture models. Ecology and evolution, 9(20), 11569-11583.

488 Duangchantrasiri, S., Umponjan, M., Simcharoen, S., Pattanavibool, A., Chaiwattana, S., Maneerat, S., 489 Kumar, N.S., Jathanna, D., Srivathsa, A. and Karanth, K.U. (2016). Dynamics of a low-density tiger 490 population in Southeast Asia in the context of improved law enforcement. Conservation 491 Biology, 30(3), pp.639-648.

492 du Preez, B.D., Loveridge, A.J. and Macdonald, D.W. (2014). To bait or not to bait: a comparison of cameratrapping methods for estimating leopard Panthera pardus density. Biological Conservation, 176, pp.153-161.

Efford, M. G. (2019). Non-circular home ranges and the estimation of population density. Ecology, 100(2), e02580.

Elliot, N.B. and Gopalaswamy, A.M. (2017). Toward accurate and precise estimates of lion density. Conservation Biology, 31(4), pp.934-943.

Fattebert, J., Robinson, H.S., Balme, G., Slotow, R. and Hunter, L. (2015). Structural habitat predicts functional dispersal habitat of a large carnivore: how leopards change spots. Ecological Applications, 25(7), pp.1911-1921.

503

Fattebert, J., Balme, G. A., Robinson, H. S., Dickerson, T., Slotow, R., \& Hunter, L. T. (2016). Population 504 recovery highlights spatial organization dynamics in adult leopards. Journal of Zoology, 299(3), 153162. 
505 Gelman, A. and Rubin, D.B. (1992). Inference from iterative simulation using multiple

506

507

508

509

510

511

512

513

514

515

516

517

518

519

520

521

522

523

524

525

526

527

528

529

530

531

532

533

534 sequences. Statistical science, 7(4), pp.457-472.

Gopalaswamy, A.M., Royle, J.A., Delampady, M., Nichols, J.D., Karanth, K.U. and Macdonald, D.W. (2012a). Density estimation in tiger populations: combining information for strong inference. Ecology, 93(7), pp.1741-1751.

Gopalaswamy, A.M., Royle, J.A., Hines, J.E., Singh, P., Jathanna, D., Kumar, N.S. and Karanth, K.U. (2012b). Program SPACECAP: software for estimating animal density using spatially explicit capture-recapture models. Methods in Ecology and Evolution, 3(6), pp.1067-1072.

Hamilton, W.J., Tilson, R. L., \& Frank, L. G. (1986). Sexual monomorphism in spotted hyenas, Crocuta crocuta. Ethology, 71(1), 63-73.

Havmøller, R. W., Jacobsen, N. S., Scharff, N., Rovero, F., \& Zimmermann, F. (2020). Assessing the activity pattern overlap among leopards (Panthera pardus), potential prey and competitors in a complex landscape in Tanzania. Journal of Zoology, 311(3), 175-182.

Hayward, M. W. (2006). Prey preferences of the spotted hyaena (Crocuta crocuta) and degree of dietary overlap with the lion (Panthera leo). Journal of Zoology, 270(4), 606-614.

Hayward, M.W., Henschel, P., O'brien, J., Hofmeyr, M., Balme, G. and Kerley, G.I.H. (2006). Prey preferences of the leopard (Panthera pardus). Journal of Zoology, 270(2), pp.298-313.

Henschel, P., Malanda, G. A., \& Hunter, L. (2014). The status of savanna carnivores in the Odzala-Kokoua National Park, northern Republic of Congo. Journal of Mammalogy, 95(4), 882-892.

Holekamp, K. E., \& Dloniak, S. M. (2010). Intraspecific variation in the behavioral ecology of a tropical carnivore, the spotted hyena. In Advances in the Study of Behavior (Vol. 42, pp. 189-229). Academic Press.

Holmern, T., Nyahongo, J., \& Røskaft, E. (2007). Livestock loss caused by predators outside the Serengeti National Park, Tanzania. Biological conservation, 135(4), 518-526.

Höner, O. P., Wachter, B., East, M. L., \& Hofer, H. (2002). The response of spotted hyaenas to long-term changes in prey populations: functional response and interspecific kleptoparasitism. Journal of Animal Ecology, 71(2), 236-246.

Höner, O. P., Wachter, B., East, M. L., Runyoro, V. A., \& Hofer, H. (2005). The effect of prey abundance and foraging tactics on the population dynamics of a social, territorial carnivore, the spotted hyena. Oikos, 108(3), 544-554. 
535 Jacobson, A. P., Gerngross, P., Lemeris Jr, J. R., Schoonover, R. F., Anco, C., Breitenmoser-Würsten, C., ...

536 \& Laguardia, A. (2016). Leopard (Panthera pardus) status, distribution, and the research efforts across 537 its range. PeerJ, 4, e1974.

538 Karanth, K.U. (1995). Estimating tiger Panthera tigris populations from camera-trap data using capture539 recapture models. Biological conservation, 71(3), pp.333-338.

540 Karanth, K. U., \& Nichols, J. D. (1998). Estimation of tiger densities in India using photographic captures and recaptures. Ecology, 79(8), 2852-2862.

Karanth, K. U., Nichols, J. D., Kumar, N. S., \& Hines, J. E. (2006). Assessing tiger population dynamics using photographic capture-recapture sampling. Ecology, 87(11), 2925-2937.

Kisame, F.E., Wanyama, F., Buhanga, E. \& Rwetsiba, A. (2018). Ground Counts for medium to large mammals in Lake Mburo Conservation Area. Uganda Wildlife Authority, Kampala, Uganda. Available at: https://www.ugandawildlife.org/phocadownload/conservation-publications/surveyreports/Ground-counts-for-LMNP-2018.pdf

Kruuk, H. (1972). The spotted hyena: a study of predation and social behavior. University of Chicago Press.

López-Bao, J. V., Godinho, R., Pacheco, C., Lema, F. J., García, E., Llaneza, L., ... \& Jiménez, J. (2018). Toward reliable population estimates of wolves by combining spatial capture-recapture models and noninvasive DNA monitoring. Scientific reports, 8(1), 1-8.

Martin, R.B. and de Meulenaer, T. (1988). Survey of the status of the leopard Panthera pardus in subSaharan Africa. CITES, Geneva, Switzerland.

Menaut JC (1983) The Vegetation of African Savannas. In: Bourlière F (ed) Tropical savannas, vol 13. Elsevier, Amsterdam, pp 109-150.

Miller, J.R., Pitman, R.T., Mann, G.K., Fuller, A.K. and Balme, G.A. (2018). Lions and leopards coexist without spatial, temporal or demographic effects of interspecific competition. Journal of Animal Ecology, 87(6), pp.1709-1726.

Miththapala, S., Seidensticker, J., Phillips, L.G., Fernando, S.B.U. and Smallwood, J.A. (1989). Identification of individual leopards (Panthera pardus kotiya) using spot pattern variation. Journal of Zoology, 218(4), pp.527-536.

M'soka, J., Creel, S., Becker, M. S., \& Droge, E. (2016). Spotted hyaena survival and density in a lion depleted ecosystem: The effects of prey availability, humans and competition between large carnivores in African savannahs. Biological Conservation, 201, 348-355. 
566 Mills, M. G. L., Juritz, J. M., \& Zucchini, W. (2001). Estimating the size of spotted hyaena (Crocuta crocuta)

567

568

569

570

571

572

573

574

575

576

577

578

579

580

581

582

583

584

585

586

587

588

589

590

591

592

593

594

595 populations through playback recordings allowing for non-response. In Animal Conservation forum (Vol. 4, No. 4, pp. 335-343). Cambridge University Press.

Moe, S. R., Loe, L. E., Jessen, M., \& Okullo, P. (2016). Effects of mammalian herbivores and termites on the performance of native and exotic plantation tree seedlings. Journal of applied ecology, 53(2), 323331.

Noss, A. J., Gardner, B., Maffei, L., Cuéllar, E., Montaño, R., Romero-Muñoz, A., ... \& O'Connell, A. F. (2012). Comparison of density estimation methods for mammal populations with camera traps in the $\mathrm{K}$ aa-I ya del G ran C haco landscape. Animal Conservation, 15(5), 527-535.

O'Brien, T.G. and Kinnaird, M.F. (2011). Density estimation of sympatric carnivores using spatially explicit capture-recapture methods and standard trapping grid.Ecological Applications, 21(8), pp.29082916.

O’Bryan, C. J., Braczkowski, A. R., Beyer, H. L., Carter, N. H., Watson, J. E., \& McDonald-Madden, E. (2018). The contribution of predators and scavengers to human well-being. Nature ecology \& evolution, 2(2), 229-236.

Ochieng, A., Ahebwa, W.M. and Visseren-Hamakers, I.J. (2015). Hunting for conservation? The reintroduction of sport hunting in Uganda examined. In Institutional Arrangements for Conservation, Development and Tourism in Eastern and Southern Africa (pp. 139-155). Springer, Dordrecht.

Périquet, S., Fritz, H. and Revilla, E. (2015). The Lion King and the Hyaena Queen: large carnivore interactions and coexistence. Biological reviews, 90(4), 1197-1214.

Ramesh, T., Kalle, R., Rosenlund, H. and Downs, C.T. (2017). Low leopard populations in protected areas of Maputaland: a consequence of poaching, habitat condition, abundance of prey, and a top predator. Ecology and evolution, 7(6), pp.1964-1973.

Rannestad, O.T., Danielsen, T., Moe, S.R. and Stokke, S. (2006). Adjacent pastoral areas support higher densities of wild ungulates during the wet season than the Lake Mburo National Park in Uganda. Journal of tropical ecology, 22(6), pp.675-683.

Rayan, D.M. and Linkie, M. (2015). Conserving tigers in Malaysia: A science-driven approach for eliciting conservation policy change. Biological Conservation, 184, pp.18-26.

R Development Core Team. (2019). R: A language and environment for statistical computing. Vienna, Austria: R Foundation for Statistical Computing. Retrieved from https://www.R-project.org/ 
596 Rich, L. N., Miller, D. A., Muñoz, D. J., Robinson, H. S., McNutt, J. W., \& Kelly, M. J. (2019). Sampling

597

598

599

600

601

602

603

604

605

606

607

608

609

610

611

612

613

614

615

616

617

618

619

620

621

622

623

624

625 design and analytical advances allow for simultaneous density estimation of seven sympatric carnivore species from camera trap data. Biological Conservation, 233, 12-20.

Royle, J.A., Karanth, K.U., Gopalaswamy, A.M. and Kumar, N.S. (2009). Bayesian inference in camera trapping studies for a class of spatial capture-recapture models. Ecology, 90(11), pp.3233-3244.

Sollmann, R., Furtado, M.M., Gardner, B., Hofer, H., Jácomo, A.T., Tôrres, N.M. and Silveira, L. (2011). Improving density estimates for elusive carnivores: accounting for sex-specific detection and movements using spatial capture-recapture models for jaguars in central Brazil. Biological Conservation, 144(3), pp.1017-1024.

Tierney, L. (1994). Markov chains for exploring posterior distributions. The Annals of Statistics, pp.17011728.

Tweheyo, M., Tumusiime, D. M., Turyahabwe, N., Asiimwe, A., \& Orikiriza, L. (2012). Wildlife damage and control methods around Lake Mburo National Park, Uganda. International journal of pest management, 58(1), 25-31.

Uganda Wildlife Authority (2010). Strategic action plan for large carnivore conservation in Uganda 20102020. Kampala, Uganda.

Venter, O., Sanderson, E.W., Magrach, A., Allan, J.R., Beher, J., Jones, K.R., Possingham, H.P., Laurance, W.F., Wood, P., Fekete, B.M. and Levy, M.A. (2016). Sixteen years of change in the global terrestrial human footprint and implications for biodiversity conservation. Nature communications, 7(1), pp.111.

Vissia, S., Wadhwa, R., \& van Langevelde, F. (2021). Co-occurrence of high densities of brown hyena and spotted hyena in central Tuli, Botswana. Journal of Zoology.

Van der Meer, E., Badza, M. N., \& Ndhlovu, A. (2016). Large carnivores as tourism flagship species for the Zimbabwe component of the Kavango Zambezi Transfrontier Conservation Area. African Journal of Wildlife Research, 46(2), 121-134.

Van de Weghe, J.P. (1990) Akagera, Land of Water, Grass and Fire. WWF, Brussels.

Watts, H. E., \& Holekamp, K. E. (2008). Interspecific competition influences reproduction in spotted hyenas. Journal of Zoology, 276(4), 402-410.

White, G.C. and Burnham, K.P. (1999). Program MARK: survival estimation from populations of marked animals. Bird study, 46(sup1), pp.S120-S139. 
626 Williams, P.J., Hooten, M.B., Womble, J.N. and Bower, M.R. (2017). Estimating occupancy and abundance 627 using aerial images with imperfect detection. Methods in Ecology and Evolution, 8(12), pp.16796281689.

629 Woodroffe, R. and Ginsberg, J.R. (1998). Edge effects and the extinction of populations inside protected 630 areas. Science, 280(5372), pp.2126-2128.

631

632

633

634

635

636

637

638

639

640

641

642

643 
Figure 1

Study area map of the Lake Mburo National Park

Study area map of the Lake Mburo National Park 


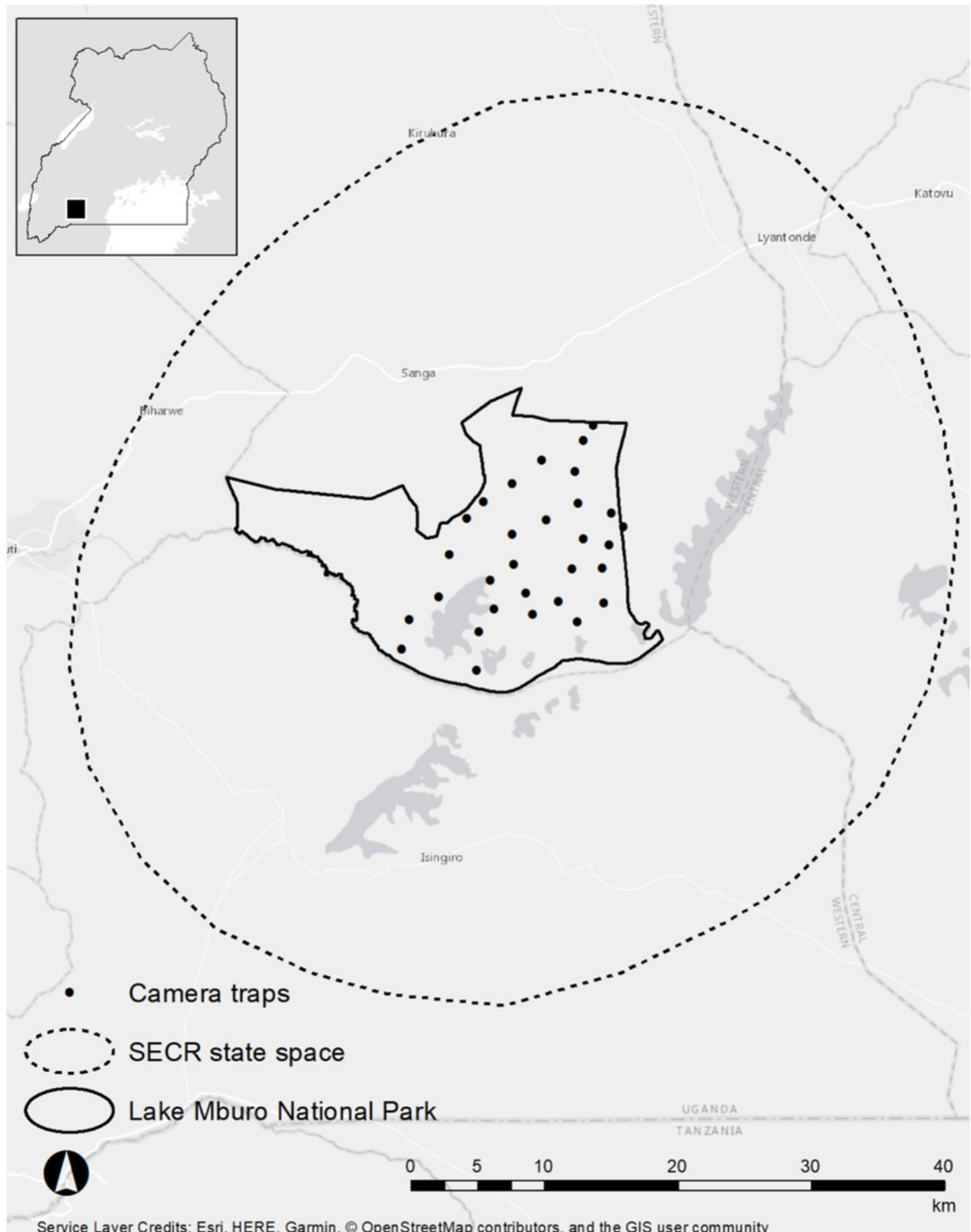




\section{Figure 2}

Individual Identification of spotted hyenas and leopards from camera traps

Individual identification information extracted from leopards and spotted hyenas in the LMNP, 2018. Slide 1 (top) denotes a female leopard captured at trap location five on sampling occasion two and ten respectively. Rosette patterns and facial spots were extracted during these two occasions. Slide 2 (bottom) denotes the spot pattern extracted from a spotted hyena captured at location 12 and 27 on sampling occasions 5 and 22 respectively.
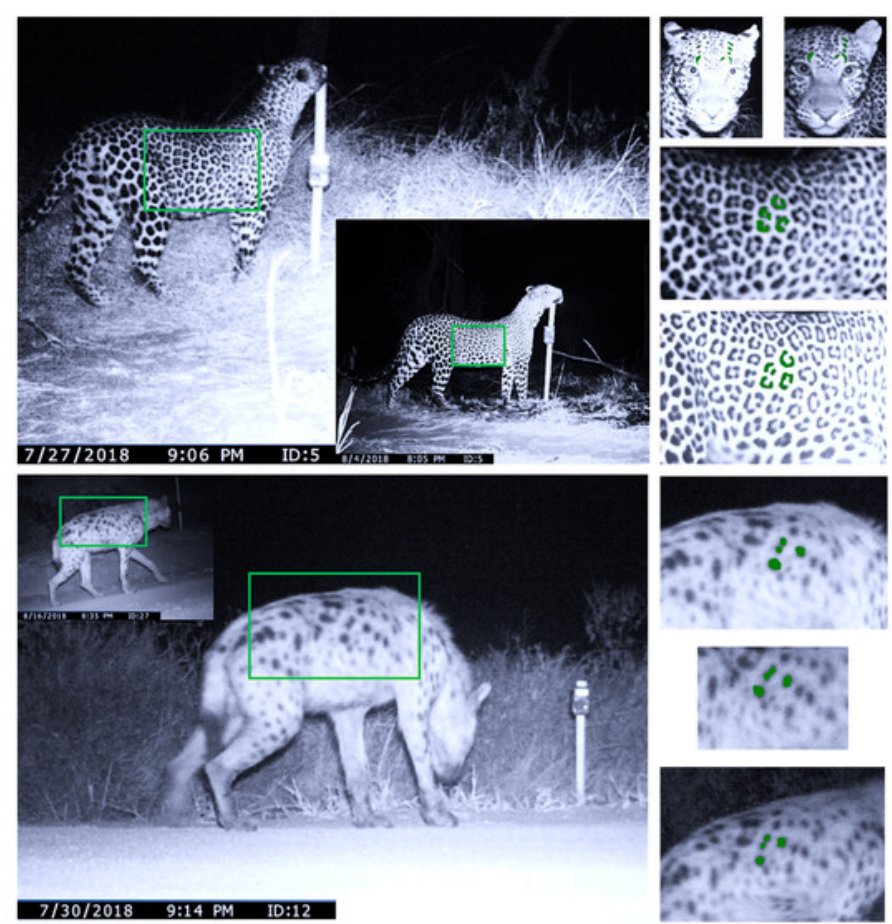


\section{Figure 3}

Densities of leopards and hyenas in Lake Mburo

African leopard and spotted hyena detection frequencies (denoted in frequency by the size of spheres) and density estimates from our SECR models, LMNP, Uganda.
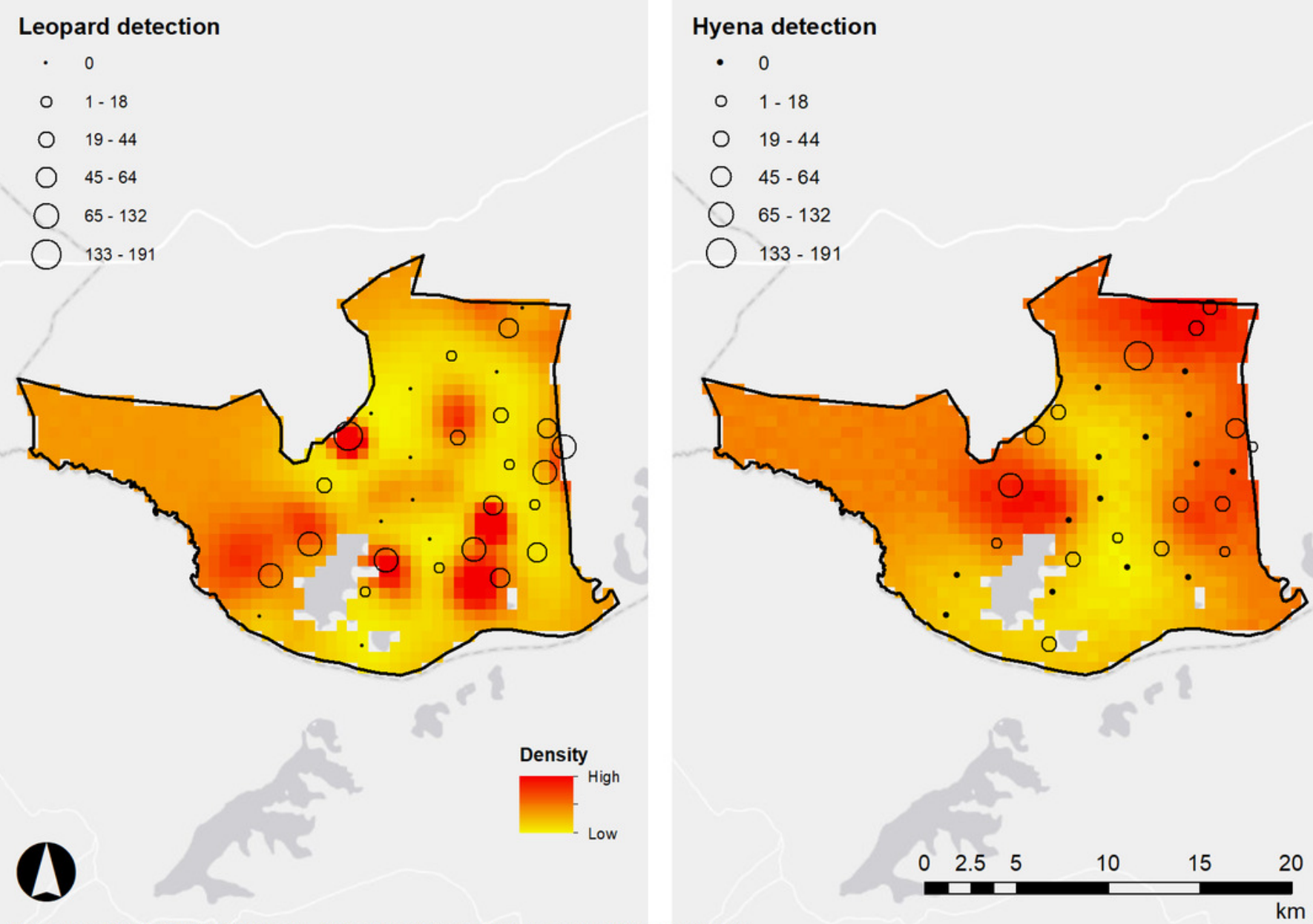


\section{Table $\mathbf{1}$ (on next page)}

Model components for secr analysis of leopard and hyena population densities

Model components for secr analysis of leopard and hyena population densities 


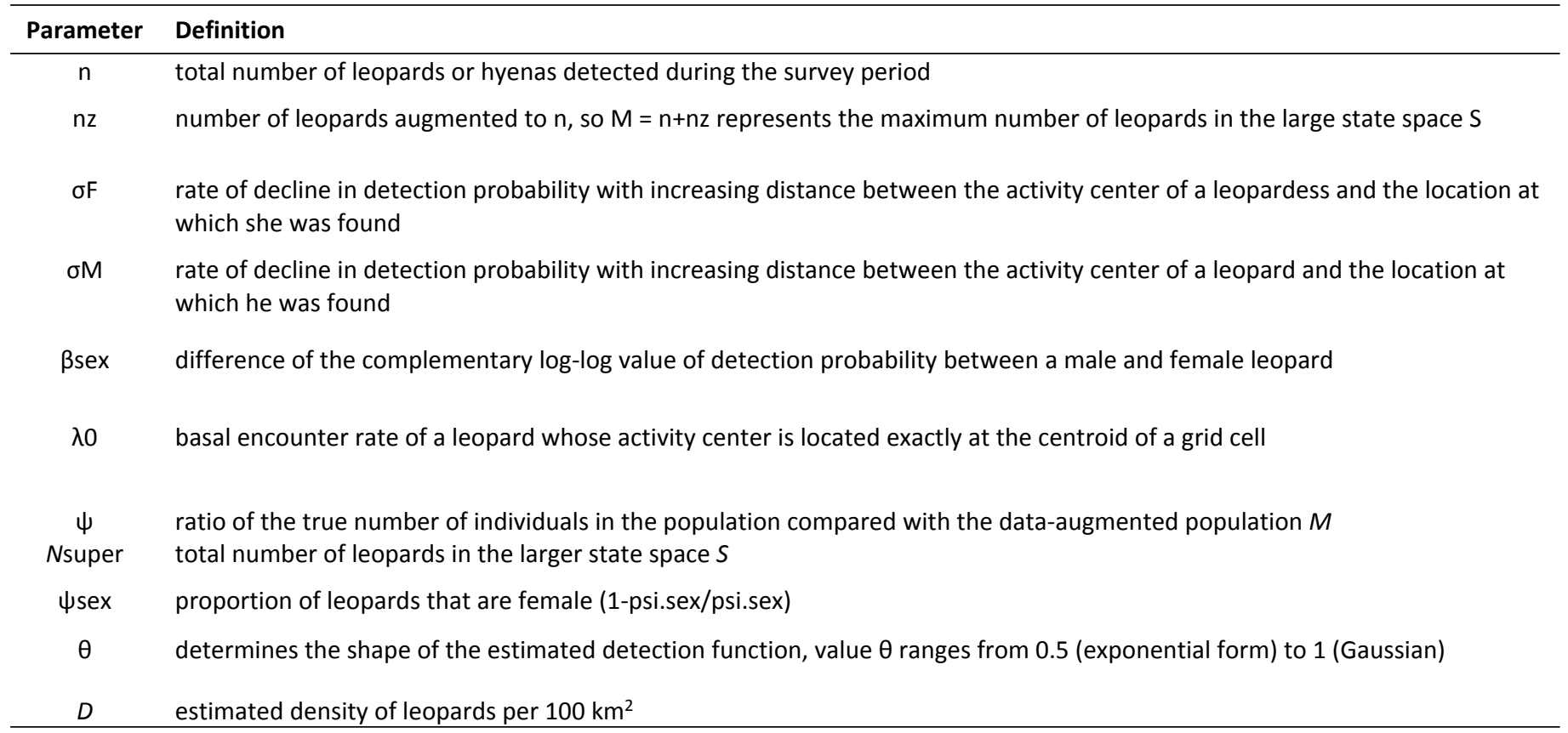




\section{Table 2 (on next page)}

Number of flanks of hyenas and leopards recorded during camera trapping in LMNP with total recaptures

Number of flanks of hyenas and leopards recorded during camera trapping in LMNP with total recaptures 


\begin{tabular}{lccccc}
\hline Species & $\begin{array}{c}\text { Number of } \\
\text { left flanks }\end{array}$ & $\begin{array}{c}\text { Number of } \\
\text { right flanks }\end{array}$ & $\begin{array}{c}\text { Number of useable } \\
\text { flanks for analysis }\end{array}$ & $\begin{array}{c}\text { Unique } \\
\text { individuals } \\
\text { identified }\end{array}$ & $\begin{array}{c}\text { Unique } \\
\text { individuals } \\
\text { recaptured }\end{array}$ \\
\hline $\begin{array}{l}\text { Spotted } \\
\text { hyena }\end{array}$ & 32 & 51 & 42 & 27 & 8 \\
Leopard & 57 & 55 & 112 & 20 & 13 \\
\hline
\end{tabular}




\section{Table 3(on next page)}

SECR models from the Lake Mburo survey

Models used to generate our density analyses for leopards and spotted hyenas in the LMNP, Uganda, 2018. We present the model number, Bayes p-value to signify model adequacy and the marginal likelihood values used to select our models, and number of iterations used to achieve convergence. 


\begin{tabular}{lccccc}
\hline Species & $\begin{array}{c}\text { Model } \\
\text { number }\end{array}$ & $\begin{array}{c}\text { Bayes } p- \\
\text { value }\end{array}$ & $\begin{array}{c}\text { Marginal } \\
\text { likelihood }\end{array}$ & $\begin{array}{c}\text { Total } \\
\text { iterations }\end{array}$ & $\begin{array}{c}\text { Burn in required to reach } \\
\text { convergence }\end{array}$ \\
\hline 1 & 0.71 & -62893.814 & 52000 & 42000 \\
Leopards & 2 & 0.71 & -62885.778 & 50000 & 20000 \\
& 3 & 0.72 & -62784.534 & 80000 & 2000 \\
& 4 & 0.71 & -62729.456 & 50000 & 20000 \\
& 5 & 0.61 & -55615.556 & 50000 & 20000 \\
$\begin{array}{l}\text { Spotted } \\
\text { Hyenas }\end{array}$ & 6 & 0.76 & -62985.962 & 50000 & 20000 \\
\hline & 1 & 0.62 & -41030.296 & 11000 & 6000 \\
\hline
\end{tabular}

1 


\section{Table 4 (on next page)}

Literature review of recent SECR leopard studies

A review of 17 recent SECR studies performed on leopards in the last 5 years from the peerreviewed literature. Some studies used a combination of maximum likelihood and Bayesianbased modelling approaches and therefore contain 2 or more estimates. We excluded the following studies for the following reasons:Goswami and Ganesh 2014 - no error reporting around estimatesKittle et al. 2017 - SECR results of tracks places results in contentionRich et al. 2019 - estimate is not directly reported only a figure is present*We examined the first ten pages of Google Scholar and limited the studies in this table to a) those using SECR and b) being published in the last 5 years. 


\begin{tabular}{|c|c|c|c|c|c|}
\hline Study name & Location & Habitat type & $\begin{array}{l}\text { Model used to } \\
\text { estimate density }\end{array}$ & $\begin{array}{c}\text { Density estimate } \\
\text { (leopards } / 100 \mathrm{~km} 2 \text { ) }\end{array}$ & $\mathrm{SD}(\mathrm{SE})$ \\
\hline Balme et al. 2019 & Sabi-Sands Game Reserve, South Africa & $\begin{array}{l}\text { Semi-wooded } \\
\text { savanna }\end{array}$ & $\begin{array}{l}\text { Borchers and } \\
\text { Efford } 2008\end{array}$ & 11.80 & 2.60 \\
\hline Borah et al. 2014 & Manas National Park, India & $\begin{array}{l}\text { Tropical forest } \\
\text { and mountains }\end{array}$ & $\begin{array}{l}\text { Borchers and } \\
\text { Efford } 2008\end{array}$ & 3.40 & 0.82 \\
\hline $\begin{array}{l}\text { Braczkowski et al. } \\
2016\end{array}$ & $\begin{array}{c}\text { Phinda Private Game Reserve, South } \\
\text { Africa }\end{array}$ & Savanna & Royle et al. 2009a & 3.55 & 1.04 \\
\hline $\begin{array}{l}\text { Braczkowski et al. } \\
2016\end{array}$ & $\begin{array}{l}\text { Phinda Private Game Reserve, South } \\
\text { Africa }\end{array}$ & Savanna & $\begin{array}{l}\text { Borchers and } \\
\text { Efford } 2008\end{array}$ & 3.40 & 1.20 \\
\hline $\begin{array}{l}\text { Devens et al. } \\
2018\end{array}$ & Baviaanskloof mountains, South Africa & $\begin{array}{l}\text { Mountain fynbos } \\
\text { and forest }\end{array}$ & Royle et al. 2009a & 0.24 & 0.10 \\
\hline $\begin{array}{l}\text { Devens et al. } \\
2018\end{array}$ & Langeberg mountains, South Africa & $\begin{array}{l}\text { Mountain fynbos } \\
\text { and forest }\end{array}$ & Royle et al. 2009a & 1.89 & 0.30 \\
\hline $\begin{array}{l}\text { Du Preez et al. } \\
2014\end{array}$ & Bubye Valley Conservancy, Zimbabwe & $\begin{array}{l}\text { Mopane } \\
\text { woodland } \\
\text { (savanna) }\end{array}$ & $\begin{array}{l}\text { Borchers and } \\
\text { Efford } 2008\end{array}$ & 5.28 & 0.89 \\
\hline $\begin{array}{l}\text { Du Preez et al. } \\
2014\end{array}$ & Bubye Valley Conservancy, Zimbabwe & $\begin{array}{l}\text { Mopane } \\
\text { woodland } \\
\text { (savanna) }\end{array}$ & Royle et al. 2009a & 5.46 & 1.14 \\
\hline $\begin{array}{l}\text { Hedges et al. } \\
2015\end{array}$ & Kenyir Wildlife Corridor, Malaysia & Dipterocarp forest & $\begin{array}{l}\text { Borchers and } \\
\text { Efford } 2008\end{array}$ & 3.30 & 1.28 \\
\hline $\begin{array}{l}\text { Hedges et al. } \\
2015\end{array}$ & Kenyir Wildlife Corridor, Malaysia & Dipterocarp forest & Royle 2011 & 3.06 & 0.91 \\
\hline $\begin{array}{l}\text { Kittle and Watson } \\
2017\end{array}$ & Horton Plains, Sri-Lanka & Montane forest & $\begin{array}{l}\text { Borchers and } \\
\text { Efford } 2008\end{array}$ & 13.40 & 6.3 \\
\hline $\begin{array}{l}\text { Ngoprasert et al. } \\
2017\end{array}$ & $\begin{array}{c}\text { Ban Krang, Kaeng Krachan National Park, } \\
\text { Thailand }\end{array}$ & Evergreen forest & $\begin{array}{l}\text { Borchers and } \\
\text { Efford } 2008\end{array}$ & 2.50 & 1.20 \\
\hline Qi et al. 2015 & Laoye mountains, China & Deciduous forest & Royle et al. 2009a & 0.62 & 0.15 \\
\hline $\begin{array}{l}\text { Rahman et al. } \\
2018\end{array}$ & $\begin{array}{l}\text { Ujong Kulon National Park, Java, } \\
\text { Indonesia }\end{array}$ & Tropical forest & $\begin{array}{l}\text { Borchers and } \\
\text { Efford } 2008\end{array}$ & 12.80 & 1.99 \\
\hline $\begin{array}{l}\text { Rahman et al. } \\
2018\end{array}$ & $\begin{array}{l}\text { Ujong Kulon National Park, Java, } \\
\text { Indonesia }\end{array}$ & Tropical forest & Royle et al. 2009a & 11.54 & 1.22 \\
\hline $\begin{array}{l}\text { Ramesh et al. } \\
2017\end{array}$ & Ndumo Game Reserve, South Africa & $\begin{array}{l}\text { Woodland } \\
\text { savanna }\end{array}$ & Royle et al. 2009a & 1.60 & - \\
\hline $\begin{array}{l}\text { Ramesh et al. } \\
2017\end{array}$ & Western Shores, South Africa & Coastal savanna & Royle et al. 2009a & 8.40 & - \\
\hline $\begin{array}{l}\text { Rostro Garcia et } \\
\text { al. } 2018\end{array}$ & Srepok wildlife sanctuary, Cambodia & $\begin{array}{l}\text { Dry deciduous } \\
\text { forest }\end{array}$ & Royle et al. 2009a & 1.00 & 0.40 \\
\hline Selvan et al. 2014 & Pakke Tiger Reserve, India & Tropical forest & $\begin{array}{l}\text { Borchers and } \\
\text { Efford } 2008\end{array}$ & 2.82 & 1.20 \\
\hline $\begin{array}{l}\text { Strampelli et al. } \\
2018\end{array}$ & Xonghile Game Reserve, Mozambique & $\begin{array}{l}\text { Woodlands and } \\
\text { thickets (savanna) }\end{array}$ & $\begin{array}{l}\text { Borchers and } \\
\text { Efford } 2008\end{array}$ & 2.59 & 0.96 \\
\hline
\end{tabular}




\begin{tabular}{|c|c|c|c|c|c|}
\hline $\begin{array}{l}\text { Swanepoel et al. } \\
2015\end{array}$ & Farming matrix, Waterberg, South Africa & $\begin{array}{l}\text { Livestock and } \\
\text { game farms }\end{array}$ & $\begin{array}{l}\text { Borchers and } \\
\text { Efford } 2008\end{array}$ & 6.59 & 5.20 \\
\hline $\begin{array}{l}\text { Swanepoel et al. } \\
2015\end{array}$ & Lapalala Game Reserve, South Africa & $\begin{array}{l}\text { Mountain } \\
\text { bushveld } \\
\text { (dystrophic } \\
\text { savanna) } \\
\text { Mountain }\end{array}$ & $\begin{array}{c}\text { Borchers and } \\
\text { Efford } 2008\end{array}$ & 5.35 & 2.93 \\
\hline $\begin{array}{l}\text { Swanepoel et al. } \\
2015\end{array}$ & $\begin{array}{c}\text { Welgevonden Game Reserve, South } \\
\text { Africa }\end{array}$ & $\begin{array}{l}\text { bushveld } \\
\text { (dystrophic } \\
\text { savanna) }\end{array}$ & $\begin{array}{l}\text { Borchers and } \\
\text { Efford } 2008\end{array}$ & 4.56 & 1.35 \\
\hline Thapa et al. 2014 & Parsa Wildlife Reserve, Nepal & $\begin{array}{l}\text { Dry deciduous } \\
\text { forest }\end{array}$ & Efford et al. 2004 & 3.78 & 0.85 \\
\hline Thapa et al. 2014 & Parsa Wildlife Reserve, Nepal & $\begin{array}{l}\text { Dry deciduous } \\
\text { forest }\end{array}$ & Royle et al. 2009a & 3.48 & 0.83 \\
\hline
\end{tabular}




\section{Table 5 (on next page)}

Spotted hyena densities recorded in the literature

Spotted hyena density estimates using SECR and camera trapping in six locations across subSaharan Africa. 


\begin{tabular}{|c|c|c|c|c|c|}
\hline Study name & Location & Habitat type & $\begin{array}{l}\text { Model used } \\
\text { to estimate } \\
\text { density }\end{array}$ & $\begin{array}{c}\text { Density } \\
\text { estimate } \\
\text { (hyenas/100 } \\
\text { km2) }\end{array}$ & SD (SE) \\
\hline Vissia et al. 2021 & Central Tuli, Botswana & $\begin{array}{l}\text { Riverine woodland and } \\
\text { shrub savanna }\end{array}$ & $\begin{array}{l}\text { Borchers and } \\
\text { Efford } 2008\end{array}$ & 14.90 & 2.23 \\
\hline Rich et al. 2019 & $\begin{array}{l}\text { Moremi Game Reserve and } \\
\text { cattle matrix, Botswana }\end{array}$ & Semi-wooded savanna & $\begin{array}{l}\text { Borchers and } \\
\text { Efford } 2008\end{array}$ & 11.80 & 2.60 \\
\hline Briers-Louw 2017 & $\begin{array}{c}\text { Majete Game Reserve, } \\
\text { Malawi }\end{array}$ & $\begin{array}{c}\text { Tropical dry } \\
\text { woodland/miombo } \\
\text { savanna woodland }\end{array}$ & $\begin{array}{l}\text { Royle et al. } \\
2009\end{array}$ & 2.69 & 0.48 \\
\hline De Blocq 2014 & $\begin{array}{c}\text { uMhkhuze Game Reserve, } \\
\text { South Africa }\end{array}$ & Semi-wooded savanna & $\begin{array}{l}\text { Royle et al. } \\
2009\end{array}$ & 10.59 & 2.1 \\
\hline O'Brien and Kinnaird 2011 & Mpala Ranch, Kenya & $\begin{array}{c}\text { Semi-wooded } \\
\text { savanna/cattle ranch }\end{array}$ & $\begin{array}{l}\text { Borchers and } \\
\text { Efford } 2008\end{array}$ & 4.93 & 1.7 \\
\hline
\end{tabular}

